\title{
USE OF SZCZECIIN'S SWIMMINMG POOLS FOR THE AQUA FITNESS ACTIVITY IN 2012 AND 2019
}

\author{
Jarosław Nadobnik, 1, A, B, D, E Aleksander Wiażewicz², B, E \\ 1 ORCID: 0000-0002-5477-5405. University of Szczecin, Faculty of Health and Physical Education, Institute of Physical Culture Sciences, \\ Poland \\ 2 ORCID: 0000-0002-8301-3004. Poland \\ A Study Design; ${ }^{\mathrm{B}}$ Data Collection; ${ }^{\mathrm{D}}$ Manuscript Preparation; ${ }^{\mathrm{E}}$ Founds Collection
}

Address for correspondence:

Jarosław Nadobnik

Institute of Physical Culture Sciences, University of Szczecin

Al. Piastów 40B, blok 6 ,

71-065 Szczecin, Poland

E-mail: jaroslaw.nadobnik@usz.edu.pl

Ahstract The available literature analysed the recommendations and optimal conditions for conducting aqua fitness classes. It was decided to check whether these guidelines are related to the practical use of facilities for conducting this type of recreational activities. The research problem was undertaken to assess the use of local swimming pools for recreational aqua fitness classes and changes in their use in 2012 and 2019.

Methods. The study covered all functioning swimming pools within the city of Szczecin, in $2012(n=17)$ and $2019(n=16)$. In order to collect the necessary data, the document analysis technique (load lists of individual facilities and lists of places where aqua fitness classes were conducted by individual entities) and the interview technique (with persons working in the aforementioned facilities, possessing the necessary information, and with the managers of individual businesses that offered aqua fitness classes in Szczecin's swimming pools) were used.

Results. Both in 2012 and 2019, the use of Szczecin's swimming pools for recreational aqua fitness was considered satisfactory. Changes in the use of Szczecin's swimming pools for the purposes of recreational aqua fitness took place over the course of several years with two swimming pools being discontinued (due to facility characteristics and conditions - temperature and water depth) and one new, private facility being opened. The number of businesses offering recreational aqua fitness services has not changed. Recreational aqua fitness classes were conducted both at typically recreational, intimate facilities located at hotels, as well as at medium and large facilities, typically sports ones.

Conclusions. The conditions, modernity of the facility and location were conducive to increased participation and utilisation of the Szczecin swimming pool base for the purposes of aqua fitness classes.

Key words physical recreation, aqua fitness, sports facilities 


\section{Introduction}

Already in ancient Rome, the water environment was used for hygiene, healing and relaxation. In the 4th century BC Hippocrates emphasised the health effects of water. For the first time, the term hydrotherapy was used in the 19th century to name therapeutic treatments using water (Zysiak-Christ, Figurska, Stasikowska, 2010).

K. Pietrusik and K. Pietrusik and B. Mroczek (2003) emphasised the merits of Dr Kenneth Cooper, who in the 1960s took up the subject of health training for people of various ages, based on aerobic energy sources. Over time, new types of aerobics were developed and became very popular with Americans. One of the variations was the transfer of aerobics from gyms to swimming pools.

The first thoughts about conducting classical aerobics classes in an aquatic environment appeared in the United States in the late 1980s. According to B. Zysiak-Christ et al. (2010), the pioneer of aqua aerobics in the world was Dr Mary Sanders, who created the foundations of "Wave Aerobics“ based on traditional gymnastics in water with the use of music. Around 1992, the broader term ,aqua fitness' began to be used in the USA.

The pioneers of this field in Poland were Figurska and Stasikowska, who in 1999 adapted the main principles of the new form of classes to Polish reality. Using their own experience, in 2001, the authors created a training programme for OM Aqua instructors and opened the Open Mind Health \& Fitness Idea School (Zysiak-Christ et al., 2010). K. Pietrusik $(2005,2007,2008)$ emphasised that aqua fitness appeared in Poland in the early 1990 s, and its growing popularity was influenced by the socio-political and economic transformations of that period.

Attempts were made to place the new discipline in the "fitness world“, listing aqua aerobics as one of the most well-known and popular forms of aerobic classes (Grodzka-Kubiak, 2002; Sornowska, 2006), situating it among mixed forms (due to the type of impact) and among pro-health forms (Zysiak-Christ et al., 2010).

O. Kuzminska (1998) accepted aqua aerobics as one of the dynamically developing directions of gymnastic dance („gym-dance“). J. Klukowski (2009) mentioned aqua fitness as a very effective element of health training.

In aqua aerobics classes, various equipment and devices are used in order to improve the participant's body buoyancy, additional mobilisation, make the classes more attractive and increase their effectiveness and intensity by increasing the water resistance (Davies, 1997; Pietrusik, 2005; Radomski, 2003; Stasikowska, 2001; Zysiak-Christ et al., 2010). Some of these have been developed specifically for the new discipline. Also, existing equipment is used, which has been modified and adapted to the conditions of aquatic environment. The most popular are: buoyancy belts, pool noodles, balls, discs (aqua discs), dumbbells, resistance shoes (aqua twin), gloves, bicycles (sharkbike, hydro bike) (Davies, 1997; Pietrusik, 2005; Pietrusik, 2007; Pietrusik, 2008; Pietrusik, Mroczek, 2003; Sornowska, 2006; Stasikowska, 2001; Zysiak-Christ et al., 2010).

Due to the diversity of aqua fitness participants, their different needs and expectations or the equipment used, different types of classes are distinguished. The most popular include: aqua aerobics (aquarobic), aqua aerobics for pregnant women (aqua KWC), aqua aerobics senior (aqua senior), aqua combo (combo), aqua cycling or noodle workout (Mosakowska, 2007; Pietrusik, 2005; Pietrusik, 2007; Pietrusik, 2008; Poliszczuk, 2009; Zysiak-Christ et al., 2010).

Extensive literature (Eider, Eider, 2006; Felix, 1995; Gedl-Pieprzyca, 1999; Grodzka-Kubiak, 2002; Kalczyński, Łubkowska, Zalewski, 1999; Lee, 1995; Mosakowska, 2007; Pietrusik, 2005; Pietrusik, 2006; Pietrusik, 2007; Pietrusik, 2008; Piotrowska-Całka, Karbownik-Kopacz, 2007; Poliszczuk, Mosakowska, 2009; Salita, 2000; ZysiakChrist et al., 2010) has highlighted the special qualities of the aquatic environment. They mentioned high safety by reducing the risk of falls or injuries, working with full relief of joints and obtaining a sense of lightness, mental 
relaxation and counteracting stress. A number of authors (Eider, 2003; Gedl-Pieprzyca, 1999; Gedl-Pieprzyca, 2000; Grodzka-Kubiak, 2002; Kalczyński, Łubkowska, Zalewski, 1999; Lee, 1995; Mosakowska, 2007; Pietrusik, 2006; Pietrusik, 2007; Pietrusik, 2008; Poliszczuk, Mosakowska, 2009) drew attention to the resistance and viscosity of water, which made it possible to strengthen skeletal and respiratory muscles without feeling excessive fatigue, resulting in increased strength, endurance and flexibility, weight loss and obtaining a slim figure, improving overall fitness. Being in the water environment gave a massage effect to the whole body (Eider, 2003; Asher, Rivara, Felix, Vance L., Dunne,1995), increased the metabolic rate and toughened the body (Eider, 2003; Felix, 1995; Pietrusik, 2005; Piotrowska-Całka, Karbownik-Kopacz, 2007). Consequently, all these factors had an impact on preventing diseases and delaying the effects of ageing (Pietrusik, 2005). Additionally, the sense of intimacy and privacy during immersion (Salita, 2000; Stasikowska, 2001), extensive corrective and compensatory functions (Pietrusik, 2005), participation in lowering blood pressure by $10-15 \%$ and increasing kidney dialysis (Sornowska, 2006), accelerated elimination of toxins (Pietrusik, 2003), reduction of cellulite (Pietrusik, Mroczek, 2003), no sweating during training (Mosakowska, 2007) and increased interpersonal contacts (Salita, 2000) have been emphasised.

Many authors (Klukowski, 2009; Mosakowska, 2007; Pietrusik, 2005; Pietrusik, 2007; Pietrusik, 2008; Pietrusik, Mroczek, 2003; Salita, 2000; Zysiak-Christ et al., 2010) enumerated the advantages of aqua aerobics classes and emphasised the egalitarianism of the training and low requirements, its application both for healthy and disabled persons, practising sports professionally and recreationally. The lack of requirements concerning the level of swimming skills was described as an additional advantage (Kuźminska, 1998; Pietrusik, 2007; Pietrusik, 2008).

Numerous physical benefits of participating in aqua fitness classes were mentioned - adaptation effects of the body in the following areas: cardiovascular work, maximum oxygen uptake, heart frequency, metabolism and energy expenditure, muscular strength, flexibility, endurance, bone content and body composition. Real effects on improved motor performance, low risk of injury, achieved feeling of relief, elimination of discomfort, improved general fitness and postural correction, reduced labour pain and risk of complications and accelerated return to previous form have been described (Barbosa, Marinho, Reis, Silva, Bragada, 2009; Eider, 2003a, b; Eider, 2004b; Gedl-Pieprzyca, 1998; Gedl-Pieprzyca, 1999; Gedl-Pieprzyca, 2000; Pietrusik, 2003, 2005, 2007, 2008; Piotrowska-Całka, Karbownik-Kopacz, 2007; Stasikowska, 2001).

The psychological benefits of participating in recreational aqua fitness activities were considered to be equally important: feelings of relaxation and relief, reduced anxiety, dominance of positive emotions, reduced levels of negative emotions, and general improvement in mental health (Gedl-Pieprzyca, 1998; Gedl-Pieprzyca, 1999; Guszkowska, 2006; Pietrusik, 2003, 2005, 2007, 2008; Piotrowska-Całka, Guszkowska, 2007; Piotrowska-Całka, Karbownik-Kopacz, 2007; Stasikowska, 2001).

The main motives for participating in aqua fitness classes were health and aesthetic motives (Poliszczuk, Mosakowska, 2007). Some authors (Kołomyjska, 2006; Pietrusik, 2005) drew attention to the future of such fields as tourism, recreation and biological regeneration, taking into account the demographic trends of the Polish society. The problem of physiological changes associated with the problem of physiological changes associated with advanced age was raised, and measures to counteract these changes were proposed (Gedl-Pieprzyca, 1998; Mosakowska, 2007; Pietrusik, 2005, 2006). In cases of osteoporosis, arthritis, obesity and in postoperative rehabilitation, aqua fitness was recommended to seniors as an attractive and safe form of fighting involutionary changes (Gedl-Pieprzyca, 1998; Pietrusik, 2005, 2006; Salita, 2000; Stasikowska, 2001). 
The literature (Davies, 1997; Felix, 1995; Lee, 1995; Pietrusik, 2005; Sornowska, 2006; Zysiak-Christ et al., 2010) describes standard gymnastic exercises: static and dynamic performed in water and proposes basic aqua aerobic steps. Some authors provided guidelines and the course of classes with such specific participants as seniors, overweight people or pregnant women (Gedl-Pieprzyca, 1998; Kołomyjska, 2006; Mosakowska, 2007; Pietrusik, 2005, 2006, 2008). Aqua fitness is also recommended for people with by-passes or scoliosis IIand III-degree scoliosis (Sornowska, 2006).

The problem of significant limitation or complete lack of physical activity of schoolage children was also raised. T. Poliszczuk and M. Mosakowska (Poliszczuk, Mosakowska, 2009) proposed to introduce aqua fitness classes to school physical education. L. Kalczyński et al. (1999) postulated extending the programme of physical education studies with aqua aerobics to encourage teachers and students to realise this type of classes during their future work at school.

Few authors (Poliszczuk, Mosakowska, 2009; Zysiak-Christ et al., 2010) wrote about the contraindications to training in water. T. Poliszczuk and M. Mosakowska (2009) listed factors, which determine the occurrence of contraindications, leaving the final decision to the doctor.

Numerous researchers (Eider, 2003a; Eider, 2004a; Eider, Eider, 2006; Gedl-Pieprzyca, 1998; Kalczyński et al.,1999; Olex-Mierzejewska, 2002; Pietrusik, 2003, 2005, 2006; Sornowska, 2006; Zysiak-Christ, Figurska, Stasikowska, 2010) have extensively presented detailed characteristics of water aerobics and theoretical backgrounds of aqua fitness training. Issues concerning the construction and organisation of classes, the choice of exercises, the conduct of lessons, the selection and use of music and practical tips for instructors and participants were addressed. Modern trends and various types of classes were mentioned aqua fitness classes were mentioned (Mosakowska, 2007; Olex-Mierzejewska, 2002; Pietrusik, 2005, 2007, 2008; Poliszczuk, Mosakowska, 2009; Zysiak-Christ, Figurska, Stasikowska, 2010). Many authors (Eider, 2004a; Gedl-Pieprzyca, 1998; Mosakowska, 2007; Olex-Mierzejewska, 2002; Pietrusik, 2003; Pietrusik, Mroczek, 2003; Poliszczuk, 2009; Salita, 2000; Sornowska, 2006; Stasikowska, 2001; Zysiak-Christ et al., 2010) gave specific recommendations regarding the duration of the lesson, the tempo of the music and intensity of exercise, but also the characteristics of the place where aqua fitness classes can be conducted, in particular: temperature and water depth.

An indispensable element of aqua fitness classes is an appropriate venue to carry out this form of recreation. The type of swimming pool, size of the pool and bottom depth have a great impact on the type of classes. Aqua fitness classes can also be conducted in natural environment, in open waters. However, most classes are held in public indoor swimming pools. Thanks to this, participation in this type of classes is independent of the season or weather (Eider, 2004a; Eider, Eider, 2006; Gedl-Pieprzyca, 1998; Pietrusik, 2005).

In the available literature (Eider, 2006a; Gedl-Pieprzyca, 1998; Mosakowska, 2007; Olex-Mierzejewska, 2002; Pietrusik, 2003, 2005; Poliszczuk, Mosakowska, 2009; Salita, 2000; Sornowska, 2006; Stasikowska, 2001; ZysiakChrist et al., 2010), the authors provided recommendations and optimal conditions for conducting aqua fitness classes. It was decided to check whether these guidelines are related to the practical use of facilities for conducting this type of recreational activities. Due to a noticeable lack of availability of literature in this field, it was decided to undertake a research problem of evaluating the use of local swimming pools for the purposes of conducting recreational aqua fitness classes and changes in their use in a specific time interval. 


\section{Materials and Methods}

The study covered all functioning swimming pools within the city of Szczecin in 2012 and 2019. During the collection of information, deliberately, open municipal swimming pools and private backyard facilities where recreational aqua fitness classes are not conducted for a fee were not included. Swimming pools of the Szczecin House of Sport facilities complex were assumed to be 3 separate facilities.

In 2012, there were 17 active swimming pools in Szczecin. The largest group were public school facilities under the Department of Education ( $n=7)$, followed by hotel swimming pools $(n=4)$, then those managed by the Municipal Sports, Recreation and Rehabilitation Centre $(n=3)$ and private facilities $(n=2)$. The smallest part consisted of one facility belonging to a higher education institution - the Maritime Academy Swimming Pool.

In 2019, there were 16 swimming pools in Szczecin. The largest part, again, were public school swimming pools $(n=5)$, followed by hotel facilities $(n=4)$, then swimming pools managed by the Municipal Sports, Recreation and Rehabilitation Centre $(n=3)$ and private facilities $(n=3)$. Again, the Maritime Academy swimming pool was the only university facility. A census of the swimming pools is provided in Table 1.

Table 1. The Szczecin's Swimming Pools in 2012 and 2019

\begin{tabular}{|c|c|c|c|c|}
\hline \multirow[b]{2}{*}{ Aquarium } & \multirow{2}{*}{$\begin{array}{c}\text { Address } \\
\text { Jemiołowa 4A }\end{array}$} & \multirow{2}{*}{$\begin{array}{c}\text { Management } \\
\text { Private property }\end{array}$} & \multicolumn{2}{|c|}{$\begin{array}{c}\text { Activities } \\
20122019\end{array}$} \\
\hline & & & not & yes \\
\hline Sports Education Centre & Rydla Street 49 & Department of Education & yes & yes \\
\hline Fitness Club & 24 Monte Cassino Street & Private property & yes & yes \\
\hline Fitness World & pl. Rodla 10 & Hotel & yes & yes \\
\hline Upper Secondary School No. 1 & al. Piastów 12 & Department of Education & yes & not \\
\hline Secondary School No.16 & 1 Dunikowskiego Street & Department of Education & yes & yes \\
\hline Non-public Primary School „Primus“ & 27 Monte Cassino Street & Private property & yes & yes \\
\hline Novotel & 31 3-go Maja Street & Hotel & yes & yes \\
\hline Park Hotel & 1 Planty Street & Hotel & yes & yes \\
\hline Maritime Academy Swimming Pool & 9a Starzynskiego Street & College & yes & yes \\
\hline Sliver Hotel & Herman Haken Roundabout & Hotel & yes & yes \\
\hline Primary School No. 10 & 63 Kazimierza Krolewicza Street & Department of Education & yes & not \\
\hline Primary School No. 51 & 21 Jodłowa Street & Department of Education & yes & yes \\
\hline Primary School No. 56 & 22 Malczewskiego Street & Department of Education & yes & yes \\
\hline Zespol Szkol Ogolnoksztalcących nr 3 & 1 Orawska Street & Department of Education & yes & yes \\
\hline ZO SDS (10 m swimming pool) & 16 Waska Street & MOSRiR & yes & yes \\
\hline ZO SDS (25 m swimming pool) & 16 Wąska Street & MOSRiR & yes & yes \\
\hline ZO SDS (50 m Swimming Pool „The Floating Arena“) & 16 Wąska Street & MOSRiR & yes & yes \\
\hline
\end{tabular}

Legend: ZO SDS - the Szczecin Sports House Complex; MOSRiR - the Municipal Centre for Sport, Recreation and Rehabilitation.

In order to collect the necessary data, the observation method was used: the document analysis technique and the interview technique. The document analysis concerned load lists of individual facilities and lists of places where aqua fitness classes are conducted by individual operators. Interviews were conducted with persons working in the above-mentioned facilities, possessing the necessary information, and with the managers of the individual entities that offered aqua fitness classes in Szczecin's swimming pools: Interview with Ms Katarzyna Górna-Zawadzka - 
owner of Aqua Kineza company, Szczecin (2.04.2019); Interview with Mr. Grzegorz Janowski - Chief Specialist in Education Department of the Szczecin City Hall Wydzial Oświaty Urzędu Miasta Szczecin (2.04.2019); Interview with Ms Magdalena Lachowicz - The Aqua Styl, Szczecin (8.04.2019); Interview with Ms Monika Łuszczek The Aqua Styl, Szczecin (9.04.2019); Interview with Ms Ewa Stadejek - owner of the Foczka Company, Szczecin (1.04.2019). The interviews was uncategorized, unclassified and individual. The above data were collected in April 2012 and April 2019. A comparative analysis was made by confronting the results from both periods.

In 2011 in Szczecin, at the "The Floating Arena" several sports events connected with water sports of national, European and world rank took place. Among others, between 8-11 December, the 19th European Swimming Championships were held (Florkiewicz, Zwierko, Krzepota, Łubkowska, Troszczyński, 2011). The year 2012 was the first year of operation of the swimming pool after such intensive use for sports competition. The facility then became increasingly available for recreational purposes.

The year 2019 was a year of important decisions on the expansion of the Szczecin swimming pool base through the construction of a modern and multifunctional water park "Water Factory“, fulfilling both sports, recreational and educational functions. Since the announcement of the tender (16.10.2018), numerous enquiries from potential bidders have been answered, significant modifications to the terms and conditions of the contract have been made, offers submitted to the tender committee have been analysed, and procedures for applying for a loan to finance the investment have been launched (as of 19.04.2019). „According to the terms of the tender, the investment should be implemented within 30 months from the date of signing the contract".

The statistical tool of STATISTICA 13.1 was used to statistically verify the significance of the changes that occurred in the first and second surveys. A test for two structure indicators was used.

\section{Results}

In 2012, aqua fitness classes were held in 13 Szczecin swimming pools out of 17 in operation (which accounted for $76.5 \%$ utilisation of available facilities). Recreational aqua fitness classes were then conducted by 12 businesses. The names of the companies (in alphabetical order) along with the location of the classes are presented in Table 2.

In 2019, recreational aqua fitness classes were conducted at 11 Szczecin swimming pools, out of 16 available (representing a utilisation of $68.75 \%$ of available facilities). This change was not statistically significant $(p=0.3087)$. Changes in the number of facilities were due to the end of operation of the swimming pool at High School No. 1, the ongoing modernisation of the swimming pool at Primary School No. 10 and the commencement of operation of one new private facility - Aquarium. Aqua fitness classes were also run by 12 companies, however, these were not the same (5 companies ceased their aqua fitness activities while 5 new companies commenced them). The names of the companies (in alphabetical order) along with The names of companies (in alphabetical order) along with the location of classes are presented in Table 3.

Despite the differences in the type, size and purpose of the facility, aqua fitness classes were conducted in various swimming pools. Purposefully, only selected facilities, characteristic in the author's opinion, were presented and described in detail in this paper.

An example of a typical facility suitable for recreational activities was The Fitness World Swimming Pool (Figure 1). Among facilities located in hotels, it was worth mentioning, as part of a very exclusive recreation and sports complex, intended primarily for guests of the Radisson Blu hotel in Szczecin. Guests from outside the hotel 
could also use this swimming pool. The dimensions of the pool are $9.5 \mathrm{~m}$ long, $5.5 \mathrm{~m}$ wide. There were no lanes, the depth ranged from $1.25 \mathrm{~m}$ to $2 \mathrm{~m}$.

Table 2. Szczecin institutions running aqua fitness classes in 2012

\begin{tabular}{rll}
\hline No. & & Company name \\
\hline 1 & Aqua Kineza & General Secondary School Complex No. 3, 1 Orawska Street \\
\hline 2 & Aqua Mama & Park Hotel, 1 Plantowa Street \\
\hline 3 & Aqua Relax STEN-RO & Maritime Academy Swimming Pool, 9a Starzynskiego Street \\
\hline 4 & Aqua Style & Middle School No. 9, 1 Dunikowskiego Street; \\
& & ZO SDS (50 m Swimming Pool „Floating Arena“), 16 Waska Street; \\
& ZO SDS (25 m Swimming Pool), 16 Waska Street \\
\hline 5 & Aqua-Fitness & Sports Education Centre, 49 Rydla Street; \\
& Aquarius & ZO SDS (25 m Swimming Pool), 16 Waska Street \\
\hline 7 & Aquatica & Primary School No. 51, 21 Jodłowa Street \\
\hline 8 & Fitness Club & Gimnazjum nr 3, 22 Malczewskiego Street \\
\hline 9 & Fitness World & Fitness Club, 24 Monte Cassino Street \\
\hline 10 & Foczka & Fitness World, pl. Rodła 10 \\
\hline 11 & Silver Hotel & Sports Education Centre, 49 Rydla Street; \\
\hline 12 & Stemrad Sport Klub & Maritime Academy Swimming Pool, 9a Starzyńskiego Street \\
\hline
\end{tabular}

Legend: ZO SDS - Szczecin House of Sports facilities complex.

Tahle 3. Szczecin institutions running aqua fitness classes in 2019

\begin{tabular}{|c|c|c|}
\hline No. & Name of the entity & Teaching venue \\
\hline 1 & ACTIVE-GO! & Sports Education Centre, 49 Rydla Street \\
\hline 2 & Aqua Kineza & General Secondary School Complex No. 3, 1 Orawska Street \\
\hline 3 & Aqua Mama & Park Hotel, 1 Plantowa Street \\
\hline 4 & Aqua Style & $\begin{array}{l}\text { General Secondary School No. 16, } 1 \text { Dunikowskiego Street; } \\
\text { ZO SDS ( } 25 \text { m Swimming Pool), } 16 \text { Waska Street }\end{array}$ \\
\hline 5 & Aquarium & Aquarium, 4a Jemiołowa St. \\
\hline 6 & Swimming Centre & $\begin{array}{l}\text { Primary School No. 51, } 21 \text { Jodłowa Street; } \\
\text { Primary School No. 56, } 22 \text { Malczewskiego Street }\end{array}$ \\
\hline 7 & Fitness Club & Fitness Club, 24 Monte Cassino Street \\
\hline 8 & Fitness World & Fitness World, pl. Rodła 10 \\
\hline 9 & Kids and Active & Primary School No. 51, 21 Jodłowa Street \\
\hline 10 & Silver Hotel & Silver Hotel, Herman Haken Roundabout \\
\hline 11 & Stemrad Sport Klub & ZO SDS (25 m Swimming Pool), 16 Wąska Street \\
\hline 12 & Fitness Zone „AQUA GO!“ & Sports Education Centre, 49 Rydla Street \\
\hline
\end{tabular}

Legend: ZO SDS - Szczecin House of Sports facilities complex. 


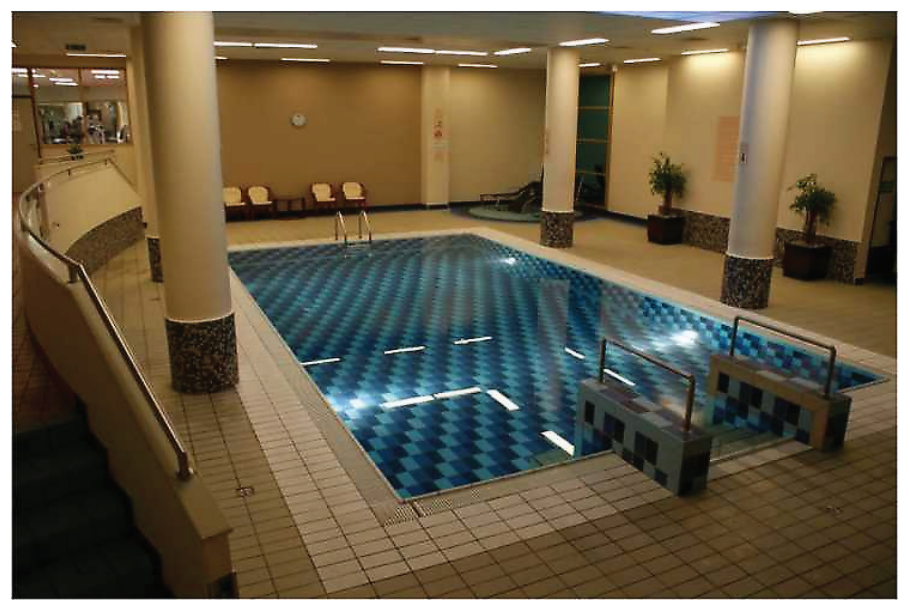

Figure 1. Fitness World Facility, pl. Rodla 10

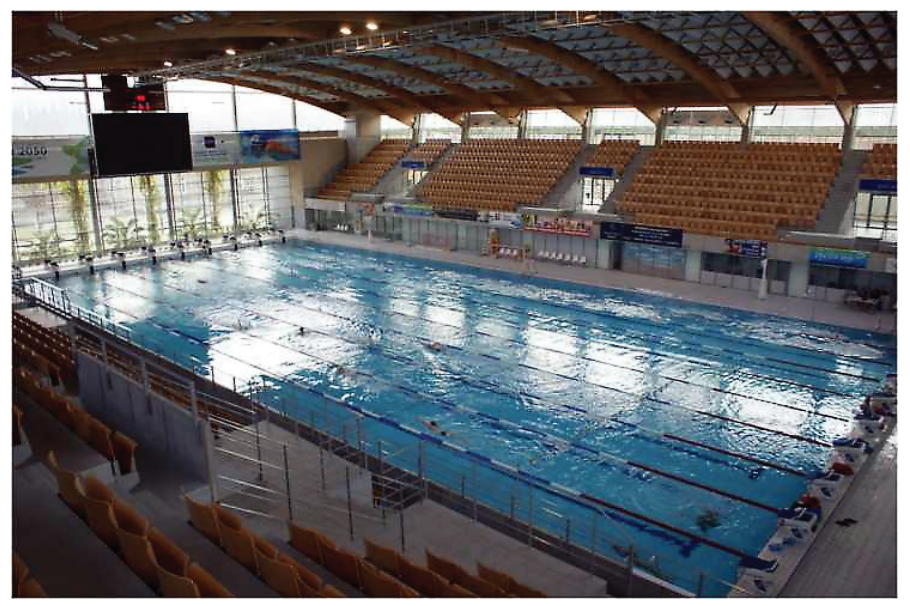

Figule 2. SDS Facilities Complex - $50 \mathrm{~m}$ Swimming Pool, Floating Arena

The Szczecin House of Sport complex, managed by the Municipal Centre for Sport, Recreation and Rehabilitation, had a sports hall, a boxing hall, a rowing pool and three facilities for sports and recreational swimming. The largest was the ,Floating Arena' - one of the most modern facilities of its kind in Europe and in the world (Figure 2). Despite the fact that it was a typical sports facility and not suitable for recreational activities, aqua fitness classes were also conducted here (in 2012). Dimensions: length - $51.3 \mathrm{~m}$, width - $25 \mathrm{~m}$, depth - $2.24 \mathrm{~m}$. There are 10 lanes, each $2.5 \mathrm{~m}$ wide. An additional option was to move the platform that divided the pool into two separate 25 -metre basins, which made it possible to use 20 lanes simultaneously. 
The swimming pool belonging to the Sports Education Centre stood out among the general school facilities and was one of the most modern swimming facilities in Szczecin (Figure 3). It combined the features of a sports and recreational swimming pool. The pool was $25 \mathrm{~m}$ long and $13.5 \mathrm{~m}$ wide. It had 6 lanes, each $2 \mathrm{~m}$ wide, and a $1 \mathrm{~m}$ wide centre pier separating 3 lanes. The depth of the trough was $2.2 \mathrm{~m}$. An interesting feature was the movable bottom with depth adjustment from $0 \mathrm{~m}$ to $2.2 \mathrm{~m}$ on 3 tracks. This allowed the implementation of various forms of recreational activities, including aqua fitness.

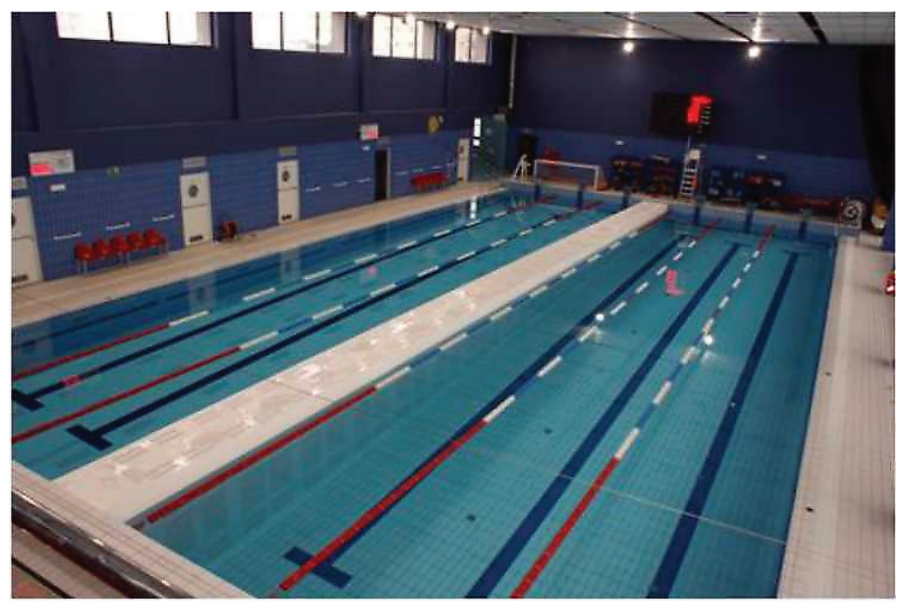

Figure 3. Swimming pool of the Sports Education Centre, 49 Rydla Street

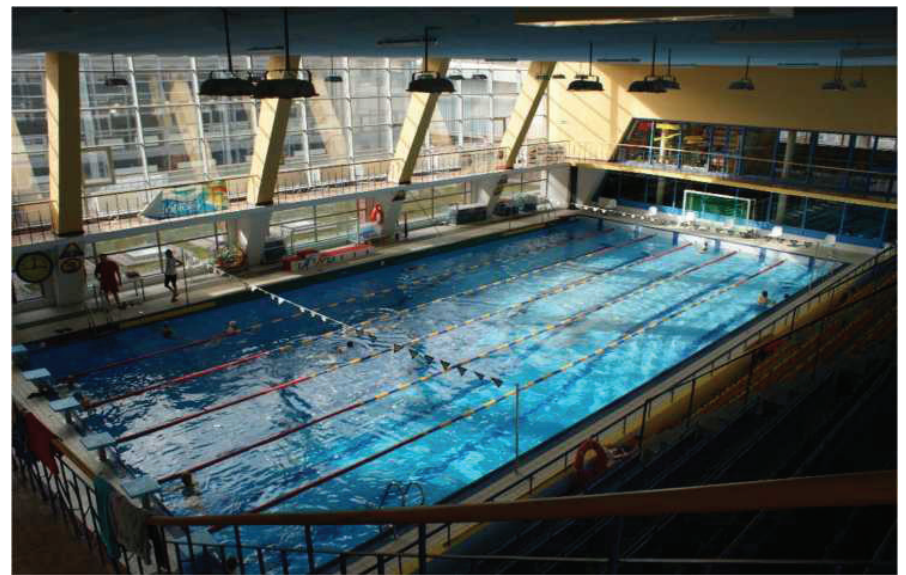

Figure 4. SDS Facilities Complex - 25 m swimming pool 
The second largest swimming pool in the Szczecin House of Sport complex was a basin measuring $25 \mathrm{~m}$ in length and $12.5 \mathrm{~m}$ in width (Figure 4). The depth was variable: from $1.25 \mathrm{~m}$ to $3.5 \mathrm{~m}$. There were 6 lanes, each $2 \mathrm{~m}$ wide. Both sports and recreational activities were conducted there. The characteristic shape of the bottom (approximately in the middle of the basin there was a steep part of the bottom, dividing the shallow and the deep side of the pool) allowed the needs of both beginners and advanced participants in aqua fitness classes to be met.

\section{Summary}

Changes in the number of Szczecin's swimming pools from 2012 to 2019 were related to the closure of one swimming pool, the ongoing refurbishment of one facility and the start of one new private swimming pool.

The facility at High School No. 1 was the smallest among the analysed Szczecin swimming pools (the dimensions of the pool were: length $-12.5 \mathrm{~m}$, width $-4.5 \mathrm{~m}$, depth - from $0.7 \mathrm{~m}$ to $1.5 \mathrm{~m}$; there were 2 lanes, $2.25 \mathrm{~m}$ each). Although the facility provided additional opportunities for student activities (Poliszczuk, Mosakowska, 2009), a decision was made to close the swimming pool. For the purposes of aqua fitness classes conducted for adults, this swimming pool was not only too small, but also too shallow. J. Eider (2004a) reported that aqua fitness classes can also be conducted in a swimming pool with shallow water $(50-80 \mathrm{~cm})$. However, many authors (Gedl-Pieprzyca, 1998; Mosakowska, 2007; Olex-Mierzejewska, 2002; Pietrusik, 2005; Poliszczuk, Mosakowska, 2009) indicated that in order to take advantage of the specific effects of the water environment on the body, the water depth should reach the level of the neck („deep water“, for people who can swim, very intensive training) or half of the chest or waist („shallow water“, for people who cannot swim, less intensive training).

The swimming pool, located in Gymnasium No. 3 at that time, was of an old type. The pool was $12.5 \mathrm{~m}$ long, $9 \mathrm{~m}$ wide and 0.9 to $1.1 \mathrm{~m}$ deep. There were 4 lanes with a width of $2.25 \mathrm{~m}$ each. The facility was in need of renovation. Aqua fitness classes were held there, but the pool did not meet the requirements necessary for sports swimming training. A decision was made to start rebuilding the swimming pool.

The creation of a new building in the Warszewo district of Szczecin was most likely due to the lack of such a facility in this part of the city to date. Development companies have made many investments in the Warszewo area, and in recent years many people living in the city centre have decided to move to the outskirts of Szczecin. Therefore there is a need for this type of facility and recreational services (including aqua fitness) in this part of the city.

Changes in the use of Szczecin's swimming pools for recreational aqua fitness activities in 2012 and 2019, involved the abandonment of the use of two swimming pools and the start of the use of one new facility.

K. Pietrusik (2005) reported that the water temperature for aqua fitness classes should be between 2430 degrees Celsius. I. Gedl-Pieprzyca (1998) gave optimal values in the range of 23-28 degrees Celsius. According to D. Olex-Mierzejewska (Olex-Mierzejewska, 2002), it should be 28-30 degrees Celsius. From the information available on the website of the Naval Academy Swimming Pool, the facility met these requirements and the water temperature was 27-28 degrees Celsius. Many authors (Gedl-Pieprzyca, 1998; Mosakowska, 2007; Olex-Mierzejewska, 2002; Poliszczuk, Mosakowska, 2009; Zysiak-Christ et al., 2010) have emphasised that aqua fitness classes can be conducted in cool water (21-27 degrees Celsius), but it should be remembered that lower exercise intensity and longer exposure of the body to such temperature may cause hypothermia. Discontinuation of the use of the Maritime Academy Swimming Pool for the purpose of conducting aqua fitness classes by the operators was probably related to too low water temperature and customers' reporting inconveniences related to it. 
Termination of aqua fitness classes at the 50-metre Floating Arena, a facility of the Szczecin House of Sport, was dictated by certain inconveniences related to the facility's characteristics. The „Floating Arena“ was a typical sports swimming pool, created and used for training and competitions in sports swimming.

The use of the facility was due to certain inconveniences caused by the characteristics of the facility. The use of a modern facility was a great incentive for participants in aqua fitness classes, but conducting such specialised classes on a single $50 \mathrm{~m}$ lane was a challenge for instructors. The depth of the water in this facility $(2.24 \mathrm{~cm})$ discouraged the participation of people in whom the lack of contact with the bottom caused uncertainty and malaise. J. Eider (2004a) recommended using swimming pools with a depth of up to $140 \mathrm{~cm}$. As pointed out by other authors (Mosakowska, 2007; Olex-Mierzejewska, 2002; Pietrusik, 2005; Poliszczuk, Mosakowska, 2009) the depth of water up to the neck level, without contact with the bottom allowed to realize only very intensive trainings, for people able to swim, in "deep water" conditions. In addition, the use of a sound system in such a large facility was problematic. Unfortunately, the pool proved unsuitable for recreational aqua fitness classes.

The new facility in Szczecin's Warszewo district was built exactly with recreational activities in mind: swimming lessons and aqua fitness classes. And that is exactly what was done there.

The changes that took place among the entities running recreational aqua fitness classes in Szczecin did not concern the number of companies. They were linked to the discontinuation of smaller, sole proprietorships or the abandonment of aqua fitness classes in favour of swimming lessons and the simultaneous appearance on the Szczecin market of the same number of businesses that were not yet operating in 2012 but were conducting their activities in 2019. These were companies focused solely on running recreational aqua fitness classes or also offering swimming lessons. Larger companies that have been active on the Szczecin market for longer or have "their own“ facilities (private swimming pools, hotels) were active in both 2012 and 2019. It can be assumed that the market for these services in Szczecin has been saturated.

The most popular facilities in Szczecin, in terms of the number of companies using the swimming pool for the purpose of conducting aqua fitness classes, are the swimming pool of the Sports Education Centre and the SDS Facilities Complex - $25 \mathrm{~m}$ swimming pool. It is likely that the location and modernity of the facility was most decisive for the large number of classes conducted and the number of participants. Both facilities were easily accessible to residents of the right- and left-bank parts of Szczecin. Both pools were modern sports and recreational complexes.

Mention should also be made of the forthcoming "The Water Factory" project - construction of a very modern and multifunctional water park, fulfilling sport, recreation and educational functions. This will allow to expand the Szczecin's swimming pool base. It may be possible to hold recreational classes at this facility, including aqua fitness classes. Certainly, the implementation of this investment will increase the interest of residents in participating in recreational activities conducted in an aquatic environment.

\section{Conclusions}

1. The number of swimming pools operating in Szczecin in 2012 and in 2019, in comparison to the needs of the population was adequate.

2. The change in the number of available pools in the period under review was related to the closure of one facility, the ongoing renovation of one swimming pool and the start of operation of one new private facility.

3. The use of Szczecin's swimming pools for recreational aqua fitness activities was found to be satisfactory in both 2012 and 2019. 
4. Changes in the use of swimming pools for recreational aqua fitness over a number of years involved the abandonment of the use of two swimming pools (due to the characteristics of the facilities and their conditions temperature and water depth) and the commencement of the use of one new, private facility (its establishment was made possible by increased demand for the given recreational services in a particular part of the city), but these were not statistically significant.

5. The number of businesses offering recreational aqua fitness activities has not changed. The termination of smaller companies was associated with the simultaneous appearance on the Szczecin market of the same number of businesses that were not yet operating in 2012. Some entities were operating in both 2012 and 2019.

6. Recreational aqua fitness classes were conducted both in typically recreational, intimate facilities located at hotels, and in medium and large facilities, typically sports ones.

\section{References}

Asher, K.N., Rivara, F.P., Felix, D., Vance L., Dunne R. (1995). Water safety Training as a potential means of reducing risk of young children's drowning. Injury prevention, 1, 228-233.

Barbosa, T., Marinho, D., Reis, V., Silva, A., Bragada, J. (2009). Physiological assessment of head-out aquatic exercises in healthy subjects: A qualitative review. Journal of Sports Science \& Medicine, 8 (2), 179-189.

Davies, S. (1997). Nauka Pływania w weekend. Wiedza i Życie.

Eider, J. (2003a). Sprawność motoryczna dziewcząt uczestniczacych w zajęciach z aerobiku wodnego. In: J. Tarasiuk, J. Kępczyński (eds.), Człowiek i środowisko przyrodnicze Pomorza Zachodniego, (I), Środowisko biotyczne (pp. 301-305). Szczecin: Oficyna In Plus.

Eider, J. (2003b). Zdrowotne wartości uprawiania aerobiku wodnego. Annales Universitas Mariae Curie-Skłodowska, Sektio D, LVIIII, suppl. XIII, 54, 295-300.

Eider, J. (2004a). Aerobik wodny. Zeszyty Naukowe Uniwersytetu Szczecińskiego. Prace Instytutu Kultury Fizycznej, 19, 5-15.

Eider, J. (2004b). Motor Fitness of Young Women Participating in Aquaaerobic. Journal of Human Kinetics, 11, 47-52.

Eider, J., Eider, P. (2006). Rekreacyjne zajęcia z aerobiku wodnego w naturalnym środowisku. In: J. Eider (ed.), Człowiek i środowisko przyrodnicze Pomorza Zachodniego. Aktywność fizyczna osób w różnym wieku - teoria i praktyka (pp. 120-125). Szczecin: Wydawnictwo Naukowe Naukowe Uniwersytetu Szczecińskiego.

Florkiewicz, B., Zwierko, T., Krzepota, J., Łubkowska, W., Troszczyński, J. (2011). Formy zajęć sportowych i rekreacyjnych oraz kierunki badań naukowych w obiekcie Floating Arena w Szczecinie. Zeszyty Naukowe Uniwersytetu Szczecińskiego, 690. Ekonomiczne Problemy Usług, 79, 641-652.

Gedl-Pieprzyca, I. (1998). Wykorzystanie ćwiczeń w środowisku wodnym poprzez aquarobic dla różnych grup sprawnościowych. In: D. Umiastowska (ed.), Aktywność ruchowa ludzi w różnym wieku, 3 (pp. 332-334). Szczecin: Albatros.

Gedl-Pieprzyca, I. (1999). Akwagimnastyka dla kobiet w ciąży. In: D. Umiastowska (ed.), Aktywność ruchowa ludzi w różnym wieku, 4 (pp. 214-218). Szczecin: Albatros.

Gedl-Pieprzyca, I. (2000). Akwagimnastyka dla pań w ciąży. In: J. Salita (ed.), Rekreacja i fitness w wodzie (pp. 29-33). Olsztyn: P.W. Glob.

Grodzka-Kubiak, E. (2002). Aerobik czy fitness. Poznań: DDK Edition.

Guszkowska, M. (2006). Wpływ regularnych ćwiczeń aerobiku na stawy emocjonalne kobiet. Medycyna Sportowa, 3, 163-168.

Kalczyński, L., Łubkowska, W., Zalewski, T. (1999). Zastosowanie akwarobiku na lekcji pływania. In: D. Umiastowska (ed.), Aktywność ruchowa ludzi w różnym wieku, 4 (219-221). Szczecin: Albatros.

Klukowski, J. (2009). Promocja aktywnego stylu życia w zdrowiu i chorobie. Lider, 12, 19-22.

Kołomyjska, G. (2006). Całoroczne zajęcia programowo-organizacyjne dla osób starszych. In: D. Umiastowska (ed.), Aktywność ruchowa ludzi w różnym wieku, 10, (2) (pp. 265-270). Szczecin: Albatros.

Kuźminska, O. (1998). Dynamiczny rozwój form tańca gimnastycznego. Kultura Fizyczna, 9-10, $27-28$.

Lee, B. (1995). Żabka, kraul i coś jeszcze... Lady Fitness, 8, 51-55.

Mosakowska, M. (2007). Aquafitness - sport całego życia. Kultura Fizyczna, 1-2, 21-26. 
Olex-Mierzejewska, D. (2002). Fitness. Teoretyczne i metodyczne podstawy prowadzenia zajęć. Katowice: UKiP J\&D. Gębka.

Pietrusik, K. (2003). Pływanie w ciąży. Body Life, 6, 18-20.

Pietrusik, K. (2005). Aqua fitness jako forma aktywności fizycznej osób w wieku seniora. Medycyna sportowa, 21 (3), 216.

Pietrusik, K. (2005). Pływanie. Nauczanie i doskonalenie oraz wybrane elementy aqua fitness. Warszawa: TKKF.

Pietrusik, K. (2006). Aqua fitness dla seniorów. Body Life, 1, 41-43.

Pietrusik, K. (2007). Moduły aqua fitness wykorzystywane w kreacji zdrowia. In: W. Siwiński, R.D. Tauber, E. Mucha-Szajek (eds.), Nowe tendencje w kulturze fizycznej i turystyce w kontekście hotelarstwa i gastronomii (pp. 451-457). Poznań: WSGiH.

Pietrusik, K. (2008). Formy aktywności fizycznej w środowisku wodnym wykorzystywane w kreacji zdrowia. In: D. Umiastowska (ed.), Aktywność ruchowa ludzi w różnym wieku, 12 (pp. 359-366). Szczecin: Albatros.

Pietrusik, K., Mroczek, B. (2003). Aqua aerobik. Body Life, 3, 24-27.

Piotrowska-Całka, E., Guszkowska, M. (2007). Effects of aqua-aerobic on the emotional states of women. Physical Education and Sport, 51 (1), 31-34.

Piotrowska-Całka, E., Karbownik-Kopacz, J. (2007). The influence of shallow and deep water exercise on the specific morphophysiological indicatiors and level of physical fitness, Medicina Sportiva, 11 (1), 11-16.

Poliszczuk, T., Mosakowska, M. (2007). Profil motywacji uczestnictwa w zajęciach aqua fitness kobiet w różnym wieku. Roczniki Naukowe Wyższej Szkoły Wychowania Fizycznego i Turystyki w Supraślu, 72-75.

Poliszczuk, T., Mosakowska, M. (2009). Aqua fitness alternatywą dla standardowych lekcji wychowania fizycznego na wszystkich etapach edukacji. Lider, 11, 13-16.

Radomski, M. (2003). Akcesoria fitness. Body Life, 1, 12-14.

Salita, J. (2000). Rekreacja i fitness w wodzie. Olsztyn: P.W. Glob.

Sornowska, D. (2006). Wprowadzenie do świata fitness. Lider, 10, 19-23.

Stasikowska, I. (2001). Aqua aerobik. Body Life, 1, 34-36.

Zysiak-Christ, B., Figurska, A., Stasikowska, I. (2010). Metodyczne podstawy aqua fitness. Wrocław: AquaFit.

Cite this anticle aS: Nadobnik, J., Wiażewicz, A. (2021). Use of Szczecin's Swimming Pools for the Aqua Fitness Activity in 2012 and 2019. Central European Journal of Sport Sciences and Medicine, 2 (34), 25-37. DOI: 10.18276/cej.2021.2-03. 